\title{
Validation of a Filipino Translation of the Children's Dermatology Life Quality Index Text Version
}

\author{
Paula Karina N. Gonzales-Carait, ${ }^{1}$ Rowena F. Genuino, ${ }^{2}$ Katrina Angela Z. Reyes ${ }^{3}$ and Belen L. Dofitas ${ }^{4}$ \\ ${ }^{1}$ Section of Dermatology, Department of Internal Medicine, De La Salle University Medical Center, Dasmariñas, Cavite, Philippines \\ ${ }^{2}$ Department of Anatomy, College of Medicine, University of the Philippines Manila, Manila, Philippines \\ ${ }^{3}$ Department of Dermatology, Rizal Medical Center, Pasig City, Philippines \\ ${ }^{4}$ Department of Dermatology, College of Medicine and Philippine General Hospital, University of the Philippines Manila, Manila, Philippines
}

\begin{abstract}
Background. Skin diseases that are longstanding or highly symptomatic can have devastating consequences in the quality of life of children. There is a need to have a validated Filipino translation of a dermatology quality of life tool for young patients with skin diseases.

Objectives. To assess the validity and reliability of the Indeks ng Kalidad ng Buhay Pang-dermatolohiya ng mga Bata (IKPaB), a Filipino translation of the Children's Dermatology Life Quality Index (CDLQI).

Methods. This cross-sectional study was conducted among children aged 4 to 16 years at a tertiary hospital outpatient department. The IKPaB was pretested and revised using focus group discussion until it was approved by the original developers for validation. Face validity was determined through cognitive debriefing interviews. Construct validity was determined by comparing IKPaB scores of participants with skin disease and without skin disease using Mann-Whitney $U$ test. Criterion validity was determined by comparing IKPaB with a validated Filipino-translated PedsQL as the criterion, using Spearman rank correlation. Internal consistency reliability was determined using Cronbach's coefficient. Multiple regression was used to correlate age, sex and disease duration.
\end{abstract}

Results. The IKPaB was assessed to be comprehensible, clear, and culturally appropriate. Among 288 participants, it showed satisfactory construct validity $(U=8849, Z=0.87 ; P=0.89)$ and internal consistency reliability $(a=0.89)$, with a negative but weak correlation with the PedsQL $\mathbb{B}(\mathrm{rho}=-0.300, P=0.000)$.

Conclusion. The IKPaB is a valid and reliable Filipino translation of CDLQI. We recommend further validation for use in clinical practice and research.

Key Words: validation, validity, reliability, quality of life, children, CDLQI, Filipino CDLQI

\section{INTRODUCTION}

Paper won $1^{\text {st }}$ place at the PGH Research Forum Presentation Observational Category, 2014, UP-PGH Manila; and $3^{\text {rd }}$ place at the Philippine Dermatological Society Residents Research Forum, 2014, Edsa Shangri-La, Manila.

Corresponding author: Paula Karina N. Gonzales-Carait, MD Section of Dermatology

Department of Internal Medicine

De La Salle University Medical Center

Dasmariñas, Cavite 4114, Philippines

Email: pau_karina@yahoo.com
Skin diseases in children and adolescents, whether acute or chronic, can have significant consequences in their quality of life. Acne patients suffer from social, psychological and emotional problems that equal those reported by patients with chronic disabling medical conditions such as asthma, epilepsy, diabetes, back pain, and arthritis. ${ }^{1,2}$ In adolescents with atopic eczema, impaired quality of life correlate with depression, anxiety, and stress symptoms. ${ }^{3}$ Vitiligo in children has been associated with higher psychosocial dysfunction in the form of anxiety and depression. ${ }^{4}$

In 2017, more than a third of 5- to 16-year-old Filipino children were diagnosed with chronic skin diseases (acne vulgaris, 20.2\%; and atopic dermatitis, $16.5 \%$ ); while acute infectious diseases accounted for 7 in the top 10 (molluscum contagiosum, 14.3\%; scabies, 12.1\%; pediculosis capitis, 
11.7\%; verruca vulgaris, 10.3\%; pityriasis versicolor, 5.0\%; tinea corporis, 4.8\%) (Philippine Dermatological SocietyHealth Information System data). Management of these skin conditions must include measurement of quality of life to determine which patients need closer monitoring and more aggressive therapy.

Of the two currently available generic dermatology children's HRQOL tools, we chose to translate and validate the Children's Dermatology Life Quality Index or CDLQI ${ }^{5}$ over the Skindex-Teen ${ }^{6}$ since the former is shorter (10 versus 22 items); broader (five domains versus only two domains); and encompasses a wider age range (both children and adolescents aged 4 to 16 years versus adolescents only).

In the initial validation study of CDLQI, there was good test-retest reliability (coefficient $=0.8) .{ }^{5}$ The CDLQI scores of dermatology pediatric outpatients (mean $=5.1, \mathrm{SD}=4.9$; $\mathrm{n}=233)$ were higher than those of normal controls $(0.4,0.7$; $\mathrm{n}=47)$ and control patients attending a general pediatric clinic $(0.7,2.5 ; \mathrm{n}=55)$. Participants with scabies $(9.5,10.5$; $\mathrm{n}=6)$, eczema $(7.7,5.6 ; \mathrm{n}=47)$, acne $(5.7,4.4 ; \mathrm{n}=40)$, and psoriasis $(5.4,5.0 ; \mathrm{n}=25)$ had significantly higher CDLQI scores than participants with moles and nevi $(2.3,2 . ; \mathrm{n}=29)$, indicating a lower quality of life in the former.

The CDLQI text version has been translated into 44 languages and showed good validity (content, criterion, and construct), internal consistency reliability (Cronbach's alpha, range 0.82 to $0.92, \mathrm{n}=6$ ), and test-retest reliability (Spearman's rank order correlation coefficient, range 0.74 to $0.97, \mathrm{n}=4) .^{7} \mathrm{~A}$ meta-analysis showed that the overall estimated CDLQI scores were highest for scabies (9.2), atopic eczema (8.5), and psoriasis (8.0). ${ }^{8}$ Although the overall mean effect on QoL was small (weighted average CDLQI score 4.6, 95\% CI 3.9, 5.4), some children experienced a very large impact on their quality of life in studies where the distribution of scores were provided (34\% of children with atopic eczema, $10 \%$ with molluscum contagiosum, and $1-5 \%$ with acne).

The Filipino translation of the CDLQI text version Indeks ng Kalidad ng Buhay Pang-dermatolohiya ng mga Bata (IKPaB $)^{9}$ - had not yet been pre-tested and validated. This study aimed to pretest and validate the IKPaB among Filipino children aged 4 to 16 with skin diseases.

\section{OBJECTIVES}

\section{General Objective}

To validate the IKPaB, a Filipino translation of the CDLQI text version.

\section{Specific Objectives}

1. To determine the face validity, construct validity, criterion validity and internal consistency, and reliability of IKPaB

2. To correlate the IKPaB scores with the age, sex, and duration of skin disease

\section{METHODS}

This two-part study was conducted according to a study protocol.

Ethical approval was given by the University of the Philippines Manila Research Ethics Board.

\section{Setting and Study Population}

This study was conducted at the University of the Philippines Manila-Philippine General Hospital (UPMPGH) outpatient department from August 2013 to August 2014. Through convenience sampling, children aged 4 to 16 years were recruited with the following criteria: native speakers of Filipino; diagnosed with skin disease at the dermatology and pediatric outpatient clinics; or without skin disease who were accompanying adult patients at any clinic. The diagnosis of the latter group was based on (1) a negative answer to the question, "Do you have any skin problem that you want to consult about?" and (2) absence of pathologic skin lesions on physical examination.

\section{Instrument}

The instrument pre-tested was the "Indeks ng Kalidad ng Buhay Pang-dermatolohiya ng mga Bata" (IKPaB), a Filipino translation of the CDLQI text version. After obtaining permission from the original CDLQI developers, the translation was started in 2009 by Dr. Rowena Genuino (Communication, Genuino 2013), and was finally approved for pretesting in March 2013. ${ }^{9}$ The translation process followed the published guidelines on translation and cultural adaptation for patient-reported outcomes. ${ }^{10}$

The IKPaB is self-explanatory and can be simply handed to patients aged 4 to 16 years. Like its original counterpart, $\mathrm{IKPaB}$ has 10 questions: 1 and 2, on symptoms and feelings of children with the skin condition; 4 to 6 , on effects of the skin condition on leisure; 7 , on conflicts in school or holidays; 9 , on sleeping disturbances; and 10 , on treatment difficulties encountered by the patient. It has four graded responses relating to frequency; each with a corresponding weighted score ranging from 0 to 3 , except for question 7.1 (regarding schoolwork), wherein there is a $5^{\text {th }}$ possible response $(5$ = di nakapasok sa eskwela) (Table 1$)$.

Table 1. Weighted score per graded response

\begin{tabular}{llc} 
Graded response (CDLQI) & Graded response (IKPaB) & $\begin{array}{c}\text { Weighted } \\
\text { Score }\end{array}$ \\
Very much & Sobra sobra & 3 \\
Quite a lot & Masyado & 2 \\
Only a little & Kaunti & 1 \\
Not at all & Hindi kailanman & 0 \\
Not applicable & Hindi naaangkop & 0 \\
Prevented school & Di nakapasok sa eskwela* & 5 \\
\hline
\end{tabular}

${ }^{*}$ Response is for question 7.1 only 
The total score is calculated by summing the individual scores of each question, resulting in a possible maximum score of 30 and a minimum of 0 . The higher the score, the more effect the skin condition has on the patient's life; hence, a poorer quality of life (Table 2).

Table 2. Interpretation of total IKPaB scores

\begin{tabular}{ll} 
Score & Interpretation \\
0 & No effect at all on patient's life \\
$2-6$ & Small effect on patient's life \\
$7-12$ & Moderate effect on patient's life \\
$13-18$ & Very large effect on patient's life \\
$19-33$ & Extremely large effect on patient's life \\
\hline
\end{tabular}

\section{Informed consent/assent}

After study objectives, as well as risks and benefits of participating in the study had been explained to the participants and parents of participants, informed consent was obtained. Participants aged 10-16 years old were also asked to sign an assent form, in addition to the informed consent signed by their parents. Verbal assent was obtained from children below 10 years old. Each enrolled participant was then given a participant code as reference.

\section{Study procedure}

\section{Part 1: Pre-testing of $I K P a B$}

The IKPaB questionnaire was self-administered to participants. Participants who had difficulty in answering the questions were assisted by the parent, guardian, or primary investigator. Questions and choices were read by the parent, guardian, or primary investigator if the participants were not able to read by themselves. Face validity of IKPaB was assessed in terms of comprehensibility, unambiguity, and relevance to the Filipino context/culture; this was done through cognitive debriefing after the participants answered the questionnaire. Participants were interviewed through focus groups of 5-10 each and verbally asked to answer 9 questions-four questions regarding the general instruction and impression of the participant on the IKPaB; and five question on each one of the ten items of IKPaB. All questions were answerable by "yes" or "no". Items on the questionnaire were then revised depending on the cognitive debriefing interview results. Pre-testing was done until all items were acceptable to all the participants. Revisions to the translation were agreed upon by the investigators and the original instrument developers (Finlay et al). Corrections on remaining spelling, diacritical, grammatical, or other errors were done before the final translation was produced (Appendix). The study then proceeded to Part 2 after all items were acceptable and original instrument developers approved the final translation.

\section{Part 2: Validity and reliability testing of $I K P a B$}

A sample size of 120 per arm (patients with skin disease and without skin disease) was estimated ( $\alpha=0.05$, power $=0.8$, Cronbach alpha expected or required $=0.83$ ) To account for a $20 \%$ non-participation rate, we recruited 288 participants.

Definition of Terms ${ }^{11}$

a. Reliability - degree to which the instrument is free from random error

b. Internal consistency reliability - consistency of answers to items in the questionnaire

c. Validity - estimate of whether a test appears to measure a certain criterion

d. Construct validity - the instrument measures the concept in question and not some other concept and that the concept is actually being measured accurately.

e. Criterion validity - correlates between the test and a criterion variable that is already held valid

\section{Administration of the IKPaB and Filipino PedsQL}

The IKPaB questionnaire was self-administered using the same methods and scoring system as previously stated. Participants aged 5 to 16 years were asked to answer a second questionnaire: "PedsQL Kalidad ng buhay ng mga bata Imbentaryo," a validated Filipino version of Pediatric Quality of Life Inventory (PedsQL) 4.0 Generic Core Instrument. ${ }^{12}$ It is used to measure health-related quality of life in healthy children and adolescents, as well as those with acute and chronic health conditions. ${ }^{13}$ Permission to use this study instrument was obtained from the developers. ${ }^{12}$

The PedsQL 4.0 Generic Core Scales are intended for young children (ages 5 to 7), children (ages 8 to 12) and teens (ages 13 to 18). ${ }^{13}$ Each is composed of 23 items comprising of 4 dimensions: physical, emotional, social, and school functioning. Responses are in a 5-point Likert scale from 0 to 4 . Items are reverse scored and linearly transformed to a 0-100 scale for standardized interpretation (Table 3). Scores of each item range from 0 to 100 , with maximum total score of 2300. The higher the PedsQL score, the better the QOL.

Table 3. PedsQL Kalidad ng buhay ng mga bata Imbentaryo weighted score per graded response

\begin{tabular}{lcc} 
Response & Weighted score & Extension of scoring scale \\
Hindi kailanman & 0 & 100 \\
Halos hindi kailanman & 1 & 75 \\
Paminsan-minsan & 2 & 50 \\
Madalas & 3 & 25 \\
Halos lagi-lagi & 4 & 0 \\
\hline
\end{tabular}

\section{Data analysis}

Participants who answered $80 \%$ of the questions in the $\mathrm{IKPaB}$ questionnaires and $50 \%$ of the questions in the PedsQL questionnaires were included in the analysis. Demographic and clinical profiles were compared using descriptive statistics. Construct validity of $\mathrm{IKPaB}$ was determined by correlating the median scores of participants 
with skin disease and those without skin disease using Mann-Whitney test. Criterion validity was tested by correlating the total IKPaB scores with total PedsQL scores using Spearman rank correlation. A correlation coefficient of $\geq 0.4$ was considered satisfactory. Internal consistency reliability of $\mathrm{IKPaB}$ was determined using item-score and total score correlation with Cronbach's $\alpha$ coefficient method. A reliability coefficient of $\geq 0.7$ was considered satisfactory. Multiple linear regression analysis was used to correlate age, gender, and duration of skin disease of participants with $\mathrm{IKPaB}$ scores.

\section{RESULTS}

\section{Part 1: Pre-testing}

Face validity of $\mathrm{IKPaB}$ questionnaire was confirmed with five revisions after six pre-testing sessions. The median age of the participants was 10.2 years old (range, 4 to 16). The mean (SD) time to complete the IKPaB was 6.4 minutes (2.9; range, 3.6 to 8). Participants from the six pretesting sessions answered all items. Revisions to the IKPaB based on the answers and comments of the participants included: the use of more appropriate word choices; rephrasing to improve sentence construction, clarificatory statements; and an additional response option (for 'not applicable') since swimming and sports are not widely practiced among Filipino children.
The final $\mathrm{IKPaB}$ version was determined to be comprehensible, unambiguous, and relevant to the sociocultural context and was approved both by the instrument developer and investigators before proceeding to part 2 of this study.

\section{Part 2: Validation of IKPaB}

\section{Study flow}

The IKPaB questionnaire was administered to 288 participants: 144 with skin disease and 144 without skin disease. (Figure 1).

\section{Characteristics of participants}

There were no baseline differences as to age and sex of participants with skin disease (mean, 9.3 years, SD 4.0; females, 56.9\%) and those without skin disease (9.2 years, 3.3; females, 52.1\%). Majority of the participants with skin disease had an acute condition (duration less than 6 months) (86/144, 59.7\%). Among the dermatologic diagnoses, majority (77/144, 53.5\%) were infectious diseases (Table 4).

\section{Results for validity and reliability}

\section{Face validity}

The IKPaB was assessed to be comprehensible, unambiguous, and culturally relevant.
Excluded ( $n=72)$

- Not meeting inclusion criteria $(n=14)$

- Declined to participate $(n=33)$

- Other reasons: agreed to participate initially but declined when called for check-up $(n=25)$

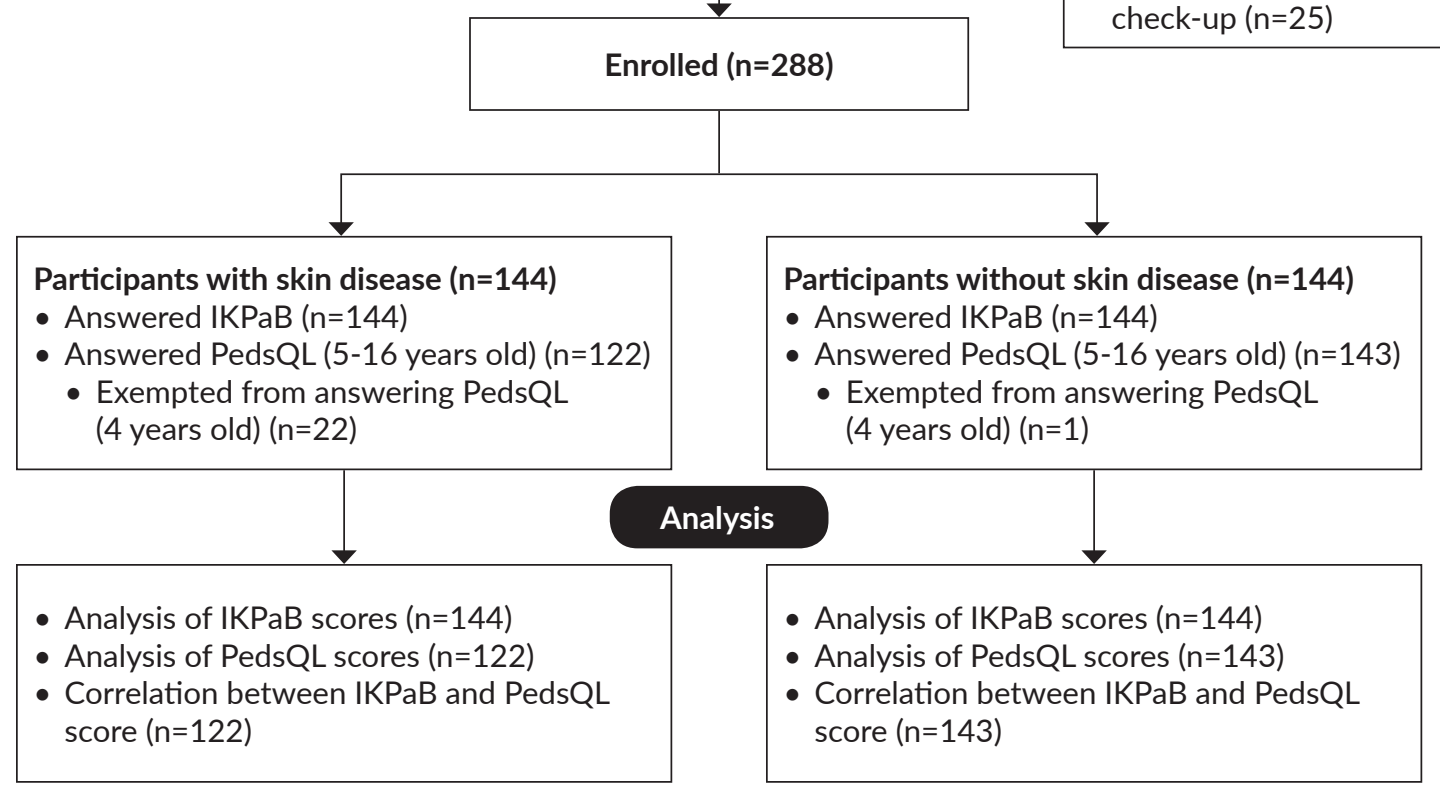

Figure 1. Study flowchart. 
Table 4. Distribution of participants according to type of skin disease and duration of skin disease

\begin{tabular}{|c|c|}
\hline Duration of Skin Disease $(n=144)$ & $\begin{array}{c}\text { No. of } \\
\text { participants (\%) }\end{array}$ \\
\hline Acute (<6 mos.) & $86(59.7)$ \\
\hline Chronic (>6 mos.) & $58(40.3)$ \\
\hline \multicolumn{2}{|l|}{ Type of Skin Diseases $(n=148)^{*}$} \\
\hline $\begin{array}{l}\text { Eczemas } \\
\text { (contact dermatitis, atopic dermatitis, dyshidrotic } \\
\text { eczema, nipple dermatitis, seborrheic eczema) }\end{array}$ & $23(16.0)$ \\
\hline $\begin{array}{l}\text { Genodermatoses } \\
\text { (neurofibromatoses) }\end{array}$ & $2(1.4)$ \\
\hline $\begin{array}{l}\text { Infectious dermatoses } \\
\text { (acute paronychia, arthropod bites, folliculitis, } \\
\text { furunculosis, impetigo contagiosa, mycetoma, } \\
\text { pediculosis capitis, pityriasis versicolor, scabies, } \\
\text { secondary bacterial infection, dermatophytosis, } \\
\text { Varicella virus infection, verruca vulgaris) }\end{array}$ & $77(53.5)$ \\
\hline $\begin{array}{l}\text { Inflammatory/immune dermatoses } \\
\text { (alopecia, chronic bullous disease of childhood, } \\
\text { dermatomyositis, lupus erythematosus, } \\
\text { psoriasis vulgaris, vitiligo) }\end{array}$ & $14(9.7)$ \\
\hline $\begin{array}{l}\text { Reactive dermatoses } \\
\text { (acute urticaria) }\end{array}$ & $3(2.1)$ \\
\hline $\begin{array}{l}\text { Tumors } \\
\text { (epidermal nevus, hemangioma, keloid, } \\
\text { Langerhans cell histiocytosis, milia, } \\
\text { pyogenic granuloma) }\end{array}$ & $7(4.9)$ \\
\hline $\begin{array}{l}\text { Miscellaneous } \\
\text { (acne vulgaris, erythema dyschromium } \\
\text { perstans, keratosis pilaris, miliaria, pityriasis } \\
\text { rubra, post-inflammatory hyperpigmentation, } \\
\text { prurigo nodularis) }\end{array}$ & $22(15.3)$ \\
\hline
\end{tabular}

\section{Construct validity}

Participants with skin disease had a significantly higher median IKPaB score (9, IQR 3 to 13) compared to those without skin disease (1, IQR 0 to 1 ) (Mann-Whitney $U$ $=4242.5, \mathrm{Z}=8.67 ; \mathrm{P}<0.05$ two-tailed). Majority of the participants diagnosed with skin disease were affected by their disease $(119 / 144,82.6 \%)$ compared to only $55 / 144$ (38.2\%) of those without skin disease. Of those participants with skin disease, majority experienced small effect on QOL due to their skin disease $(81 / 144,55.6 \%)$ (Figure 2).

\section{Criterion validity}

There was a weak negative correlation between IKPaB and PedsQL (Spearman rank correlation rho $=-0.30, \mathrm{P}=$ 0.00). This indicates that as the score of IKPaB increases, the score of PedsQL decreases-which means a lower quality of life, although the correlation is weak.

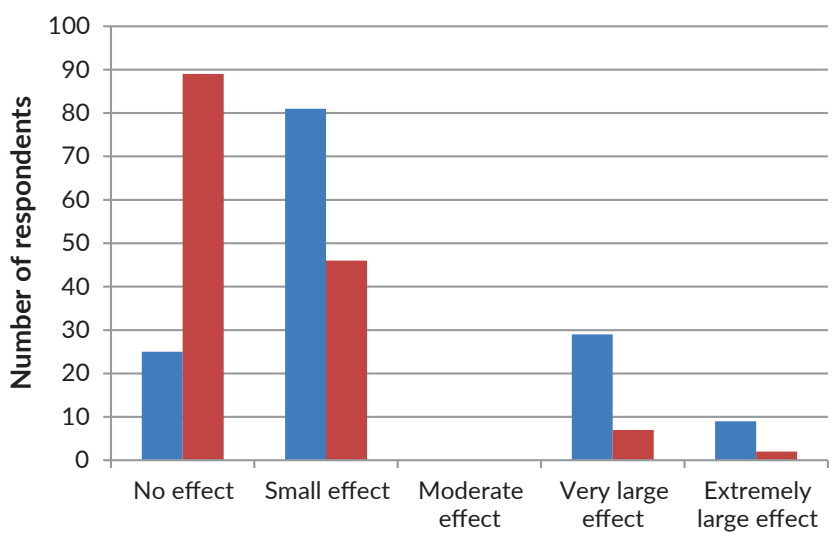

Effect on QOL based on IKPaB scores

With skin condition $\quad$ Without skin condition

Figure 2. Percentage distribution of participants according to effect on QOL based on IKPaB scores.

\section{Internal consistency reliability}

There was satisfactory internal consistency reliability (Cronbach's alpha coefficient, 0.87, 95\% CI 0.85, 0.89).

Correlation of IKPaB with age, gender, and duration of skin disease

Participants with shorter duration of skin disease tended to have higher IKPaB scores (coefficient, -0.001); however, this was not statistically significant $(P=0.14)$. Similarly, age $(P=0.79)$ and sex $(P=0.59)$ were not significantly correlated to the IKPab scores (Table 5).

Mean time to complete the questionnaires by both groups (with and without skin disease) was similar for IKPaB (4.0 mins, SD 1.7) and PedsQL (4.6 mins, SD 1.9) and within the acceptable time of 5 minutes. Response rate was $100 \%$. All items in the IKPaB were answered by all the participants.

\section{DISCUSSION}

The IKPaB was shown to be a comprehensible, unambiguous, and culturally adapted translation of the CDLQI among Filipino children aged 4 to 16 years, with good face validity, construct validity $(Z=8.67 ; \mathrm{P}<0.05)$, and internal consistency reliability (Cronbach's alpha $=0.87$ ). However, criterion validity of $\mathrm{IKPaB}$ with PedsQL as the reference criterion was below satisfactory $(\mathrm{rho}=-0.30$ ). The mean time to complete the IKPaB was 4.5 minutes. There was no correlation between $\mathrm{IKPaB}$ scores and predictor variables of gender, age, and duration of skin disease.

Table 5. Multiple linear regression coefficients for IKPaB scores using age, gender, and duration of skin disease as predictors

\begin{tabular}{lccccc} 
Predictor variable & Coefficient & SE & T stat & P-value & Confidence Interval \\
Age (in years) & 0.016 & 0.059 & -0.666 & 0.79 & $-0.100,0.131$ \\
Females & 0.238 & 0.435 & 0.547 & 0.59 & $-0.619,1.095$ \\
Duration of skin disease (in days) & -0.001 & 0.000 & 3.342 & 0.14 & $-0.244,-0.011$ \\
\hline
\end{tabular}


Cultural adaptation of the translation showed some cultural-specific differences among Filipino children, namely lack of widespread engagement in sports and their own interpretation of school time and holiday season. Previous validation studies also reported doing similar cultural adaptation procedures (Bulgarian, ${ }^{14}$ Cantonese, ${ }^{15}$ Dutch, ${ }^{16}$ Malaysian, ${ }^{17}$ and Mexican, ${ }^{18}$ and Turkish $\left.{ }^{19}\right)$.

The sample size in this study $(\mathrm{n}=288)$ was larger than the sample sizes of most previous validation studies (ranging from 6 to 379). ${ }^{7}$ However, it was conducted only in one public tertiary hospital. A multi-center study involving other settings such as private hospitals or community setting would provide a better representation of the Filipino population.

The IKPaB showed comparable construct validity to the initial UK validation study of the CDLQI (comparing children with skin disease to normal children and children with other chronic disease $)^{5}$ and the validation of the Cantonese version in Hongkong (comparing children with pityriasis rosea to those with no skin disease) ${ }^{20}$ However, there was a small group of outliers in the control group in this study $(\mathrm{n}=9)$ who did not have skin diseases on physical examination but who had high IKPaB scores, indicating a very large to extremely large effect on their quality of life. A possible reason is that they misunderstood the instructions and considered a previous skin disease as still part of symptoms within the past week.

The negative correlation $(\mathrm{rho}=-0.300, \mathrm{P}-$ value $=0.000)$ between $\mathrm{IKPaB}$ and PedsQL is expected since they have opposite scoring systems. However, the weak correlation (less than 0.4) may be due to the fact that the PedsQL is a generic tool and not specific to skin diseases. It also reflects changes in quality of life due to other non-dermatologic reasons. In contrast, previous validation studies conducted in children with specific skin diseases used disease-specific criterion questionnaires - such as Cardiff Acne Disability Index (CADI), ${ }^{21,22}$ and Childhood Atopic Dermatitis Impact Scale (CADIS $)^{23}$ - as gold standards, and had good criterion validity.

Our findings of acceptable internal consistency reliability $(\alpha=0.87)$ is congruent with previous studies showing values ranging from 0.82 to 0.92 , all above the minimum value for good internal consistency (0.70). This indicates that the homogeneity of the index and the interrelatedness of the different items were maintained in the translated Filipino CDLQI.

This study found no correlation between IKPaB scores and duration of skin disease, sex and age of participants. Similarly, there were no sex nor age differences in a previous Dutch validation study of pediatric patients with vitiligo $^{16}$ and a Turkish validation study of children with skin diseases. ${ }^{19}$ In contrast, there was strong correlation between the child's age and the CDLQI scores $\left(r_{s}=0.41\right.$; $\mathrm{p}=0.044)$ in a Portuguese validation study on children with vitiligo. They found the median CDLQI score to be significantly higher in adolescents aged 15 years and older
$($ median $=11$, interquartile range $=4.75-14.25, \mathrm{p}=0.04) .{ }^{24}$ This may signify the greater impact of a depigmenting skin disease such as vitiligo during the age wherein self-identity is critical, and that this is not gender-dependent. This same study, however, found no difference between males and females $(p=0.219)$. A meta-analysis showing that scabies, an acute skin infestation, had the highest IKPaB scores and lowest quality of life, ${ }^{8}$ is in agreement with our findings. This shows that it is not just disease chronicity that determines QoL, but also the intensity of symptoms.

\section{CONCLUSION AND RECOMMENDATIONS}

The study has shown that the IKPaB, is a reliable and valid Filipino translation of the CDLQI text version in terms of face validity, construct validity, and internal consistency reliability. There is a need to conduct further criterion validity testing using skin disease-specific QoL questionnaires. We recommend that $\mathrm{IKPaB}$ be used regularly in clinics for outcome assessment and management of skin diseases for 4- to 16-year-old Filipinos. It should be tested further in disease-specific interventional studies to monitor improvement in QoL.

\section{Statement of Authorship}

Primary author - PKNGC and KAZR did the data collection. All authors did data analysis and approved the final version submitted.

\section{Author Disclosure}

All authors declared no conflicts of interest.

\section{Funding Source}

No outsource funding was made; primary author shouldered all expenses.

\section{REFERENCES}

1. Eyüboglu M, Kalay I, Eyüboglu D. Evaluation of adolescents diagnosed with acne vulgaris for quality of life and psychosocial challenges. Indian J Dermatol. 2018; 63(2):131-5.

2. Koo J. The psychosocial impact of acne: patient's perception. J Am Acad Dermatol. 1995;32(5 Pt 3):S26-30.

3. Hon KL, Pong NH, Poon TCW, Chan DFY, Leung TF, Lai KYC, et al. Quality of life and psychosocial issues are important outcome measures in eczema treatment. J Dermatol Treat. 2015; 26(1):83-9. doi:10.3109/09546634.2013.873762.

4. Bilgiç O, Bilgiç A, Akiş HK, Eskioğlu F, Kiliç EZ. Depression, anxiety and health-related quality of life in children and adolescents with vitiligo. Clin Exp Dermatol. 2011; 36(4):360-5.

5. Lewis-Jones MS, Finlay AY. The Children's Dermatology Life Quality Index (CDLQI): Initial validation and practical use. Br J Dermatol. 1995; 132(6):942-9.

6. Smidt AC, Lai JS, Cella D, Patel S, Mancini AJ, Chamlin SL. Development and validation of Skindex-Teen, a quality-of-life instrument for adolescents with skin disease. Arch Dermatol. 2010; 146(8):865-9.

7. Salek MS, Jung S, Brincat-Ruffini LA, MacFarlane L, LewisJones MS, Basra MKA, et al. Clinical experience and psychometric 
properties of the Children's Dermatology Life Quality Index (CDLQI), 1995 - 2012. Br J Dermatol. 2013; 169(4):734-59. doi:10.1111/bjd.12437.

8. Olsen JR, Gallacher J, Finlay AY, Piguet V, Francis NA. Quality of life impact of childhood skin conditions measured using the Children's Dermatology Life Quality Index (CDLQI): a meta-analysis. Br J Dermatol. 2016; 174(4):853-61.

9. Genuino R, Dofitas B, Gonzales-Carait P. CDLQI Different Language Versions: Filipino version [Internet]. Cardiff University, Department of Dermatology. 2016 [cited 2019 Jan 10]. Available from: http://sites. cardiff.ac.uk/dermatology/quality-of-life/childrens-dermatologylife-quality-index-cdlqi/cdlqi-different-language-versions/.

10. Wild D, Grove A, Martin M, Eremenco S, McElroy S, VerjeeLorenz A, et al. Principles of good practice for the translation and cultural adaptation process for patient-reported outcomes (PRO) measures: Report of the ISPOR Task Force for Translation and Cultural Adaptation. Value Health. 2005; 8(2):94-104.

11. Streiner DL, Norman GR. Health Measurement Scales: A practical guide to their development and use (3rd ed). New York: Oxford University Press. 2003.

12. Varni J. PedsQL Translations. PedsQL Quality of Life Inventory [Internet]. [cited 2019 Jan 10]. Available from: http://www.pedsql.org/ translations.html.

13. Varni JW, Seid M, Kurtin PS. PedsQL 4.0: Reliability and validity of the Pediatric Quality of Life Inventory Version 4.0 Generic Core Scales in healthy and patient populations. Med Care. 2001; 39(8): 800-12.

14. Clayton TH, Clark SM, Britton J, Pavolv S, Radev S. A comparative study of the Children's Dermatology Life Quality Index (CDLQI) in paediatric dermatology clinics in the UK and Bulgaria. J Eur Acad Dermatol Venereol. 2007; 21(10):1436-7.

15. Chuh AAT. Validation of a Cantonese version of the Children's Dermatology Life Quality Index. Pediatr Dermatol. 2003; 20(6): 479-81.
16. Njoo MD, Bos JD, Westerhof W. Treatment of generalized vitiligo in children with narrow-band (TL-01) UVB radiation therapy. J Am Acad Dermatol. 2000;42 (2 Pt 1):245-53.

17. Noor Aziah MS, Rosnah T, Mardziah A, Norzila MZ. Childhood atopic dermatitis: a measurement of quality of life and family impact. Med J Malaysia. 2002; 57(3):329-39.

18. Ramirez-Anaya M, Macias MER, Velazquez-Gonzalez E. Validation of a Mexican Spanish version of the Children's Dermatology Life Quality Index. Pediatr Dermatol. 2010; 27(2):143-7.

19. Balci DD, Sangün O, Inandi T. Cross validation of the Turkish version of Children's Dermatology Life Quality Index. J Turk Acad Dermatol. 2007; 1:71402a.

20. Chuh AAT. Quality of life in children with pityriasis rosea: a prospective case control study. Pediatr Dermatol. 2003; 20(6):474-8.

21. Walker N, Lewis-Jones MS. Quality of life and acne in Scottish adolescent schoolchildren: use of the Children's Dermatology Life Quality Index (CDLQI) and the Cardiff Acne Disability Index (CADI). J Eur Acad Dermatol Venereol. 2006; 20(1):45-50.

22. Jankovic S, Vukicevic J, Djordjevic S, Jankovic J, Marinkovic J, Basra MKA. The Cardiff Acne Disability Index (CADI): linguistic and cultural validation in Serbian. Qual Life Res. 2013; 22(1):161-6.

23. Neri E, Agostini F, Gremigni P, Gobbi F, Casu G, Chamlin SL, et al. Italian validation of the Childhood Atopic Dermatitis Impact Scale: a contribution to its clinical application. J Invest Dermatol. 2012; 132(11):2534-43.

24. Boza JC, Giongo N, Machado P, Horn R, Fabbrin A, Cestari T. Quality of life impairment in children and adults with vitiligo: A cross-sectional study based on dermatology-specific and diseasespecific quality of life instruments. Dermatology. 2016; 232(5): 619-25. doi:10.1159/000448656. 


\section{APPENDIX}

Final version IKPaB

\section{INDEKS NG KALIDAD NG BUHAY PANG-DERMATOLOHIYA NG MGA BATA}

Participant Code:

Edad:
Sakit sa balat:

Petsa:
$\mathrm{IKPaB}$

BILANG:

PANUTO: Layunin ng palatanungang ito na sukatin kung gaano ka naapektuhan ng problema mo sa balat.

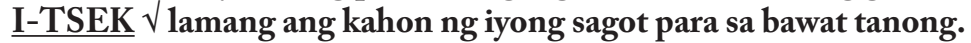

\begin{tabular}{|c|c|c|c|}
\hline 1. & $\begin{array}{l}\text { Noong huling pitong araw, } \\
\text { gaano kakati, kahapdi o } \\
\text { kasakit ang iyong balat? }\end{array}$ & $\begin{array}{l}\text { Sobra sobra } \\
\text { Masyado } \\
\text { Kaunti lang } \\
\text { Hindi kailanman } \\
\text { Hindi naaangkop (N/A) }\end{array}$ & $\begin{array}{l}\square \\
\square \\
\square \\
\square \\
\square\end{array}$ \\
\hline 2. & $\begin{array}{l}\text { Noong huling pitong araw, } \\
\text { gaano ka naging mahiyain o } \\
\text { naging malungkot dahil sa } \\
\text { iyong balat? }\end{array}$ & $\begin{array}{l}\text { Sobra sobra } \\
\text { Masyado } \\
\text { Kaunti lang } \\
\text { Hindi kailanman } \\
\text { Hindi naaangkop (N/A) }\end{array}$ & $\begin{array}{l}\square \\
\square \\
\square \\
\square \\
\square\end{array}$ \\
\hline 3. & $\begin{array}{l}\text { Noong huling pitong } \\
\text { araw, gaano naapektuhan } \\
\text { ng iyong balat ang } \\
\text { pakikipagkaibigan mo? }\end{array}$ & $\begin{array}{l}\text { Sobra sobra } \\
\text { Masyado } \\
\text { Kaunti lang } \\
\text { Hindi kailanman } \\
\text { Hindi naaangkop (N/A) }\end{array}$ & $\begin{array}{l}\square \\
\square \\
\square \\
\square \\
\square\end{array}$ \\
\hline 4. & $\begin{array}{l}\text { Noong huling pitong araw, } \\
\text { gaano ka nagbago o nagsuot } \\
\text { ng kakaiba o espesyal na } \\
\text { damit/sapatos dahil sa } \\
\text { iyong balat? }\end{array}$ & $\begin{array}{l}\text { Sobra sobra } \\
\text { Masyado } \\
\text { Kaunti lang } \\
\text { Hindi kailanman } \\
\text { Hindi naaangkop (N/A) }\end{array}$ & $\begin{array}{l}\square \\
\square \\
\square \\
\square \\
\square\end{array}$ \\
\hline 5. & $\begin{array}{l}\text { Noong huling pitong araw, } \\
\text { gaaano naapektuhan ng iyong } \\
\text { problema sa balat ang iyong } \\
\text { paglabas-labas, paglalaro o } \\
\text { ang paggawa ng mga hilig mo? }\end{array}$ & $\begin{array}{l}\text { Sobra sobra } \\
\text { Masyado } \\
\text { Kaunti lang } \\
\text { Hindi kailanman } \\
\text { Hindi naaangkop (N/A) }\end{array}$ & $\begin{array}{l}\square \\
\square \\
\square \\
\square \\
\square\end{array}$ \\
\hline 6. & $\begin{array}{l}\text { Noong huling pitong araw, } \\
\text { gaano mo iniwasan ang } \\
\text { paglangoy o iba pang isports } \\
\text { dahil sa problema mo sa balat? }\end{array}$ & $\begin{array}{l}\text { Sobra sobra } \\
\text { Masyado } \\
\text { Kaunti lang } \\
\text { Hindi kailanman } \\
\text { Hindi naaangkop (N/A) }\end{array}$ & $\begin{array}{l}\square \\
\square \\
\square \\
\square \\
\square\end{array}$ \\
\hline
\end{tabular}

\begin{tabular}{|c|c|c|c|c|}
\hline 7. & $\begin{array}{l}\text { No } \\
\square \\
\square\end{array}$ & $\begin{array}{l}\text { ng huling pitong araw, may } \\
\text { OO } \rightarrow \text { sagutan ang LETTE } \\
\text { WALA dahil bakasyon (sum } \\
\text { holiday) } \rightarrow \text { sagutan ang LE }\end{array}$ & $\begin{array}{l}\text { asok ka ba sa eskwela? } \\
\text { A } \\
\text { ner break, sembreak, o } \\
\text { TER B }\end{array}$ & \\
\hline & A. & $\begin{array}{l}\text { Kung nasa eskwelahan ka } \\
\text { noong nakaraang linggo, } \\
\text { gaano naapektuhan ng } \\
\text { problema mo sa balat } \\
\text { ang iyong mga gawaing } \\
\text { pang-eskwela? }\end{array}$ & $\begin{array}{l}\text { Di nakapasok sa eskwela } \\
\text { Masyado } \\
\text { Kaunti lang } \\
\text { Hindi kailanman } \\
\text { Hindi naaangkop (N/A) }\end{array}$ & $\begin{array}{l}\square \\
\square \\
\square \\
\square \\
\square\end{array}$ \\
\hline & B. & $\begin{array}{l}\text { Kung walang pasok } \\
\text { sa eskwela dahil } \\
\text { BAKASYON (summer, } \\
\text { sembreak, pasko), } \\
\text { gaano naapektuhan ng } \\
\text { problema mo sa balat } \\
\text { ang pagpapakasaya mo } \\
\text { sa bakasyon? }\end{array}$ & $\begin{array}{l}\text { Sobra sobra } \\
\text { Masyado } \\
\text { Kaunti lang } \\
\text { Hindi kailanman } \\
\text { Hindi naaangkop (N/A) }\end{array}$ & $\begin{array}{l}\square \\
\square \\
\square \\
\square \\
\square\end{array}$ \\
\hline 8. & $\begin{array}{l}\text { No } \\
\text { gaa } \\
\text { iyo } \\
\text { par } \\
\text { par } \\
\text { tan } \\
\text { iba }\end{array}$ & $\begin{array}{l}\text { ng huling pitong araw, } \\
\text { o kalaking abala sa } \\
\text { dahil sa balat mo, ang } \\
\text { sungutya, panunukso, } \\
\text {-aapi, pagtatanong- } \\
\text { ing o pag-iwas sa iyo ng } \\
\text { g tao? }\end{array}$ & $\begin{array}{l}\text { Sobra sobra } \\
\text { Masyado } \\
\text { Kaunti lang } \\
\text { Hindi kailanman } \\
\text { Hindi naaangkop (N/A) }\end{array}$ & $\begin{array}{l}\square \\
\square \\
\square \\
\square \\
\square\end{array}$ \\
\hline 9. & $\begin{array}{l}\text { No } \\
\text { gaa } \\
\text { tulc } \\
\text { sa }\end{array}$ & $\begin{array}{l}\text { ng huling pitong araw, } \\
\text { o naapektuhan ang } \\
\text { g mo ng iyong problema } \\
\text { alat? }\end{array}$ & $\begin{array}{l}\text { Sobra sobra } \\
\text { Masyado } \\
\text { Kaunti lang } \\
\text { Hindi kailanman } \\
\text { Hindi naaangkop (N/A) }\end{array}$ & $\begin{array}{l}\square \\
\square \\
\square \\
\square \\
\square\end{array}$ \\
\hline 10. & & $\begin{array}{l}\text { ng huling pitong araw, } \\
\text { o naging problema ang } \\
\text { jamot sa iyong balat? }\end{array}$ & $\begin{array}{l}\text { Sobra sobra } \\
\text { Masyado } \\
\text { Kaunti lang } \\
\text { Hindi kailanman } \\
\text { Hindi naaangkop (N/A) }\end{array}$ & $\begin{array}{l}\square \\
\square \\
\square \\
\square\end{array}$ \\
\hline
\end{tabular}

Siguraduhin lamang na nasagutan mo ang BAWAT tanong. Salamat.

(c) M.S. Lewis-Jones, A.Y. Finlay, Mayo 1993. Ito ay bindi dapat kopyahin ng walang pabintulot ng mga may-akda. 